\title{
Toxicity of Nanomaterials and Recent Developments in Lung Disease
}

\author{
R. Asmatulu \\ Department of Mechanical Engineering, Wichita State University \\ Fairmount, Wichita, \\ USA
}

\section{Introduction}

\subsection{Background}

Nanotechnology is the study of materials, compounds, devices, and/or systems at near atomic or molecular levels [1]. Usually, one of the dimensions of nanoproducts is between 1 $\mathrm{nm}$ and $100 \mathrm{~nm}$ length in scale. This emerging technology involves fabricating, imaging, measuring, modeling, and manipulating matter at this scale [2]. The goal of nanotechnology is to control individual atoms, molecules, or particles in order to significantly improve the physical, chemical, physicochemical, and biological properties of materials and devices for various humanitarian purposes. One of the most important aspects of nanotechnology is the greatly improved surface area-to-volume ratio at this level. It includes a broad range of highly multidisciplinary fields, such as engineering, materials science, colloidal science, physics, chemistry, pharmacy, medicine, and biology [3].

Nanomaterials can exhibit entirely different properties than their bulk-scaled conventional materials, enabling them to be appealing materials in many industrial applications [3]. For example, inert materials become catalytic materials (e.g., platinum and gold), opaque substances turn out to be transparent materials (e.g., carbon, copper), melting temperatures of solid materials are greatly reduced (e.g., gold, platinum, titanium), semiconductors become conductors (e.g., silicon, germanium), and non-combustible materials turn into combustible materials (e.g., aluminum) [1-3]. These fascinating behaviors of nanomaterials can be obtained only at nanoscale.

Nanomaterials, including nanoparticles, nanotubes, nanofibers, and nanocomposites, in the forms of metals and alloys, ceramics, polymers, and composites are all produced by nanotechnology processes and are considered to be the next generation of materials for manufacturing faster cars and planes, more powerful computers and satellites, more sensitive sensors, stronger materials for structural applications, and better micro- and nanochips and batteries [1]. This is because nanomaterials have outstanding mechanical, electrical, optical, magnetic, quantum mechanic, and thermal properties. Nanomaterials are already found in more than a thousand different products, including bacteria-free cloth, concrete, filtration units, sunscreen, car bumpers, tooth paste, polymeric coatings, solar and fuel cells, lithium-ion batteries, tennis rackets, wrinkle-resistant clothing, and optical, electronic, and sensing devices [2]. In the near future, the use of nanomaterials will 
drastically increase worldwide. It is expected that the global market growth of nanotechnology is on track to reach one trillion dollars, and 50 percent of all new products will be nanotechnology-oriented by the year 2015 [20,21].

\subsection{Motivation}

Throughout the manufacturing, transportation, storage, consumption, and waste disposal of nanomaterials, the air, water, soil, and food (e.g., vegetables, fruits, and animal products) can become contaminated, resulting in countless public concerns $[8,22]$. Nanoparticles can also remain airborne for hundreds of kilometers and penetrate humans, animals, and plant cells, causing many known and unknown side effects [4]. Nanomaterials mainly enter the human body by inhalation, ingestion, and/or contact through skin and persist in the system. Most human-made nanomaterials do not appear in the environment, so living organisms may not have an appropriate immune system to deal with these nanoscale products $[5,8]$. Recent studies show that when some nanomaterials of varying surface areas, sizes, shapes, charges and energy, and compounds interact with human and animal cells or organs, they can damage or kill those cells or organs, block blood flow, and cause serious diseases [6,7]. Illnesses associated with nanomaterials include bronchitis, asthma, lung and liver cancer, Parkinson's disease, Alzheimer's disease, Crohn's disease, heart disease, and colon cancer $[4,5]$. Understanding the mechanisms and causes of nanomaterials will allow us to find efficient cures for lung diseases and other related illnesses associated with nanomaterials and devices $[8,9]$.

Since nanomaterials are a new set of materials produced by entirely new manufacturing techniques, there are currently no specific rules and regulations for many of them. Hence, these uncertainties bring nanoethics and bioethics in research, development, and education to seek and examine the potential risks and rewards of the applications of these materials, as well as societal, economic, moral, health, and other broader human implications of advances in this technology [23-27].

Objectives of this study are as follows: $i$ ) to understand the surface properties of nanomaterials, $\mathrm{ii}$ ) to determine the effects of nanoscale surfaces on the lung and other related diseases associated with nanomaterials, $\mathbf{i i i}$ ) to find possible protection methods for students, scientists, engineers, medical personnel, policymakers, and regulators working in the field, and $i v$ ) to inform these groups of people about progress and future developments in the field [4,]. Some of these objectives and future developments are summarized below.

\section{Surface properties of nanomaterials}

Surface chemistry, surface potential, surface area, and particle size are dominating factors in the toxicity of nanomaterials [4-8]. These materials can react with the body, stay inert, and/or interact with a system based on their surface properties, and they can settle in the body for a long period of time [9-11]. It has been stated that almost all properties of nanoparticles are entirely different than their bulk-size counterparts [2]. Since the properties of nanomaterials are completely different, their toxicity could be different as well. Recent toxicological studies have demonstrated that particles less than $100 \mathrm{~nm}$ induce toxicity in many cell-cultured human and animal models [4-11]. Figure 1 shows the comparison of rat macrophage cells (raw cells) with different particles. As can be seen, nanoparticles are several orders of magnitude smaller than human and animal cells. They can be even smaller than DNA, pathogens, proteins, and enzymes [1]. Previous studies confirm that the smaller 
the particle size, the higher the toxicity $[8,14]$. Note that human macrophages are approximately twice as large as rat macrophages, so nanoparticle penetration may be easier for human macrophages or other larger living entities.

The surface area of nanomaterials is exponentially high when the size is at nanoscale, so the surface chemistry (e.g., surface charge, zeta potential, and surface energy) of materials is drastically changed. The high surface area of nanomaterials means numerous unbonded atoms, resulting in huge surface interaction with surrounding tissues. Hence, surface chemistry can basically provide information about the mechanisms of biological toxicity of nanomaterials in cells $[4,6]$. For example, gold, silver, and platinum are chemically inactive and usually do not interact directly with the body at bulk scale. Allergic reactions and other toxic effects of these inert materials are at minimum level in bulk or at microscale. However, because of their size, the surface of nanoscale materials can be chemically activated to harm the surrounding cells or organs [4]. Some nanomaterials have higher surface-to-volume ratios, which can be also responsible for the shape-dependent surface reactivity and toxicity [12-17].


Fig. 1. Various images of cells and nanoparticles: A) rat raw cells (macrophages) at lower magnification, B) TEM image of magnetic nanoparticles with average diameter of $10 \mu \mathrm{m}$, C) comparison of raw macrophage cells, and D) drawings of particles at various size ranges. 
Nanoparticles tend to aggregate due to intermolecular interactions, such as electrostatic, hydrophobic, and van der Waals, which makes the aggregation process easier [39]. Particle agglomeration, stability, and distribution can be related to surface charge and zeta potential values of nanoparticles in an aqueous media. The surface charge mainly regulates the stability of the nanoparticles [1]. At lower surface charges, nanoparticles usually agglomerate and make a larger cluster [2]. It has been reported that the toxicity of single particles is much higher than that of aggregated nanoparticles [4].

The toxicity of nanomaterials can be minimized using different chemical processes, such as surface treatment, modification, and functionalization [39-42]. In this way, surface energy and surface charge of nanoparticles can be changed via additions of chemicals (e.g., surfactants, electrolytes, and polymers). These chemicals include (but are not limited to) citric acid, tetramethyl ammonium hydroxide, gum Arabic, sodium dodecyl sulfate, and other carboxyl and amine functionalization groups. As a result, the surface functionalization process will help nanomaterials perform at less toxic levels in the body or in other applications [6,7].

\section{Toxicity of nanomaterials and lung disease}

Nanomaterials can enter the human body by various routes, such as breathing, eating, and touching the skin (Figure 2) $[4-8,29,45]$. Skin is the first defense barrier against the outside environment and is typically the first place on the body that is exposed to nanomaterial toxicity. Larger micron-scale particles normally cannot pass through skin and will not cause any health concerns. For the past few years, toxicological studies demonstrated that particles less than $100 \mathrm{~nm}$ in diameter induce toxicity in cell-cultured models as well as animal models [28-31]. It is also more difficult to remove nanoparticles from the body than the same kinds of larger particles. Table 1 shows the relationship between nanoparticle size and possible toxicity to living cells [8]. As is known, several kinds of sicknesses can be expected from nanomaterials that accumulate in the body, including inflammation of the airways, bronchitis, asthma, emphysema, lung cancer, neurodegenerative diseases, cardiovascular effects, liver cancer, Parkinson's disease, Alzheimer's disease, Crohn's disease, heart disease, and colon cancer $[4,40]$.

Unless functionalized, most nanomaterials are not stable in in-vitro conditions, so their stability is dependent on several factors, such as $\mathrm{pH}$, ionic strength, solubility, thermodynamic feasibility, concentration, kinetic facility of electron transfers, and redox conditions of biological media [5]. The toxicity of nanomaterials can occur through three different mechanisms in the body: $i$ ) dissolution process of nanomaterials in biological media, ii) catalyst properties of nanomaterials, and iii) reduction and oxidation (Redox) evolution of the surfaces [4-6].

In one study, an organ exposed to nanoparticles was analyzed, and the results indicated that the smaller particles diffused into the respiratory system faster than microscale particles [5]. It was also found that nanoparticles penetrate into cells and, by transcytosis, across epithelial and endothelial cells and into lymph circulation to reach very sensitive parts of the body, such as the nervous system, bone marrow, brain, lymph nodes, spleen, and heart. This study concluded that surface coating and in-vivo surface modification could reduce the side effects of those nanoparticles [6,7]. Figure 3 shows the nanoparticles of a lead compound and scanning transmission electrograph of ceria nanoparticles exposed to clearing sludge $[29,45]$. 


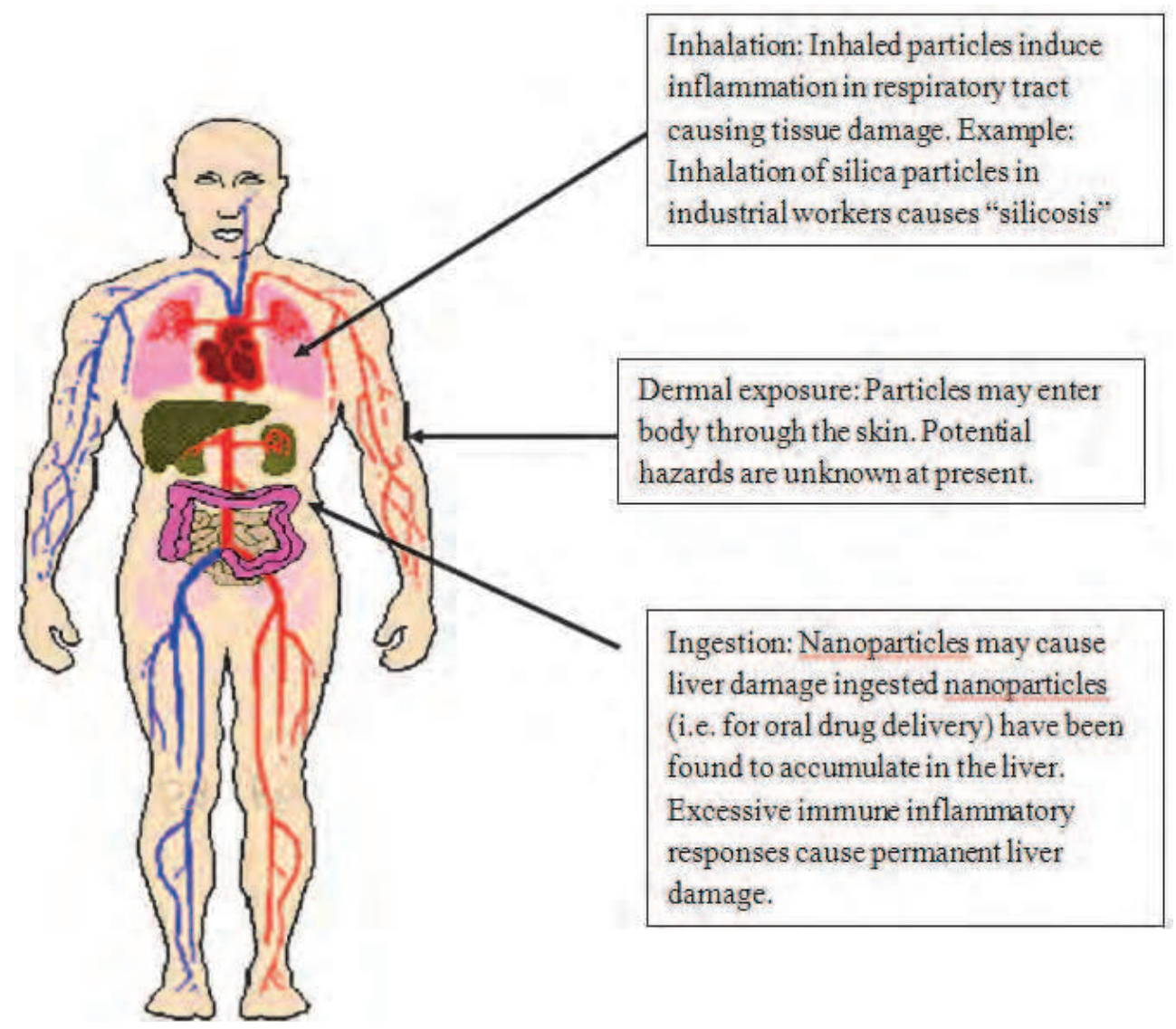

Fig. 2. Entrances of nanoscale materials into the body through inhalation, dermal exposure, and ingestion, resulting in many potential hazards [25].

Lung disease involves many illnesses, such as bronchitis, asthma, chronic obstructive pulmonary disease, influenza, pneumonia, tuberculosis, cancer, and many other breathingrelated illnesses [5]. Recent studies have shown that some lung diseases, such as bronchitis and asthma, are directly linked to the uptake of nanomaterials. After the inhalation of nanomaterials, they can be deposited throughout the entire respiratory system, beginning in the nose to the inside of the lung, which has airways that transport air combined with nanomaterials in (mostly) and out (rarely) of the body. Because of the larger surface area of lungs, nanoparticles have a primary entry route. Although larger particles (more than 10 $\mu \mathrm{m})$ tend to be deposited in the upper part of the respiratory system and removed easily by the body through coughing and sneezing, smaller nanoscale particles can reach the gas exchange surfaces and remain there for a longer period of time. This is where the real problem begins [8].

Broken surfaces and other damage in the lung and other parts of the respiratory system accelerate the penetration of nanomaterials into the surrounding tissue, resulting in fastergrowing lung diseases [4]. Also, when nanoparticles enter the blood stream, they can be 


\begin{tabular}{|c|c|c|c|c|}
\hline $\begin{array}{l}\text { Type of } \\
\text { Material }\end{array}$ & $\begin{array}{l}\text { Particle Size } \\
\quad(\mathrm{nm})\end{array}$ & $\begin{array}{c}\text { Surface } \\
\text { Area } \\
\left(\mathrm{m}^{2} / \mathrm{g}\right)\end{array}$ & $\begin{array}{c}\text { Charge/Zeta } \\
\text { Potential (mV) }\end{array}$ & Biological Toxicity \\
\hline \multirow[t]{2}{*}{ Alumina } & 116 & 13.37 & $45-50$ & $\begin{array}{c}\text { Protein (BSA) adsorption with } \\
\text { time }\end{array}$ \\
\hline & & & (pH 5.5-6.5) & $\begin{array}{c}\text { IEP shifts with } \mathrm{pH} \text { and surface } \\
\text { area }\end{array}$ \\
\hline $\begin{array}{c}\text { PEG } \\
\text { Quantum } \\
\text { Dots }\end{array}$ & 10 & - & - & $\begin{array}{l}\text { Retention of } Q \text { dots in liver, } \\
\text { spleen, and bone marrow }\end{array}$ \\
\hline MWCNT & $10-20$ & $40-300$ & - & $\begin{array}{l}\text { Cytotoxicity: alveolar } \\
\text { macrophages at high dose }\end{array}$ \\
\hline \multirow[t]{2}{*}{ SWCNT } & 1.4 & 270 & - & $\begin{array}{l}\text { Cytotoxicity: alveolar } \\
\text { macrophages at low dose; }\end{array}$ \\
\hline & & & & $\begin{array}{c}\text { transient inflammatory and cell } \\
\text { injury }\end{array}$ \\
\hline \multirow[t]{5}{*}{ Titania } & 300nm(rutile) & 6 & - & $\begin{array}{l}\text { Short-term reversible } \\
\text { inflammation }\end{array}$ \\
\hline & $\operatorname{Rods}(20-233)$ & 26.5 & - & $\begin{array}{l}\text { Short-term reversible } \\
\text { inflammation }\end{array}$ \\
\hline & (anatase rods) & & - & $\begin{array}{l}\text { Minor adverse lung tissue } \\
\text { reaction }\end{array}$ \\
\hline & Spherical(5-6) & 169.4 & - & $\begin{array}{l}\text { Short-term reversible } \\
\text { inflammation }\end{array}$ \\
\hline & $\begin{array}{l}\text { (anatase spherical } \\
\text { powder) }\end{array}$ & & - & $\begin{array}{l}\text { Minor adverse lung tissue } \\
\text { reaction }\end{array}$ \\
\hline Quartz & $1.5 \mu \mathrm{n}$ & 4 & - & High pulmonary toxicity \\
\hline \multirow[t]{2}{*}{ PTFE } & 20 & - & - & Cell death-15 min. exposure \\
\hline & 130 & - & - & No ill effects \\
\hline \multirow[t]{3}{*}{$\begin{array}{l}\text { Emulsifying } \\
\text { Wax }\end{array}$} & $\begin{array}{l}74.7 \pm 53.4 \\
\text { (neutral) }\end{array}$ & - & $-14.1 \pm 2.1$ & $\begin{array}{c}\text { No BBB; permeation ability in } \\
\text { low conc. }\end{array}$ \\
\hline & $\begin{array}{l}127.1 \pm 70.6 \\
\text { (anionic) }\end{array}$ & - & $-59 \pm 2.9$ & $\begin{array}{c}\text { No BBB; permeation ability in } \\
\text { low concentrations }\end{array}$ \\
\hline & $\begin{array}{l}97.2 \pm 68.9 \\
\text { (cataionic) }\end{array}$ & - & $45.2 \pm 3.5$ & $\begin{array}{l}\text { Toxic at brain } \\
\text { microvasculaturue } \\
\text { endothelium }\end{array}$ \\
\hline Ceria & $3-5$ & - & - & $\begin{array}{l}\text { Radio protection, nontoxic at } \\
\text { low/medium dose }\end{array}$ \\
\hline Yttria & 50 & - & - & $\begin{array}{l}\text { Neuroprotection against } \\
\text { oxidative stress }\end{array}$ \\
\hline
\end{tabular}

Table 1. Relationship between nanoparticle size and nanoparticle toxicity [8]. 
delivered to organs and tissues in the entire body, including the brain, heart, liver, kidneys, spleen, bone marrow, and nervous system [40]. Unlike larger particles, nanoparticles can reach the cell mitochondria and cell nuclei of these organs, which in turn cause DNA mutation and induce major structural damage and cell death $[25,28,41]$. In this case, particle size and shape are the major factors in determining particle toxicity.

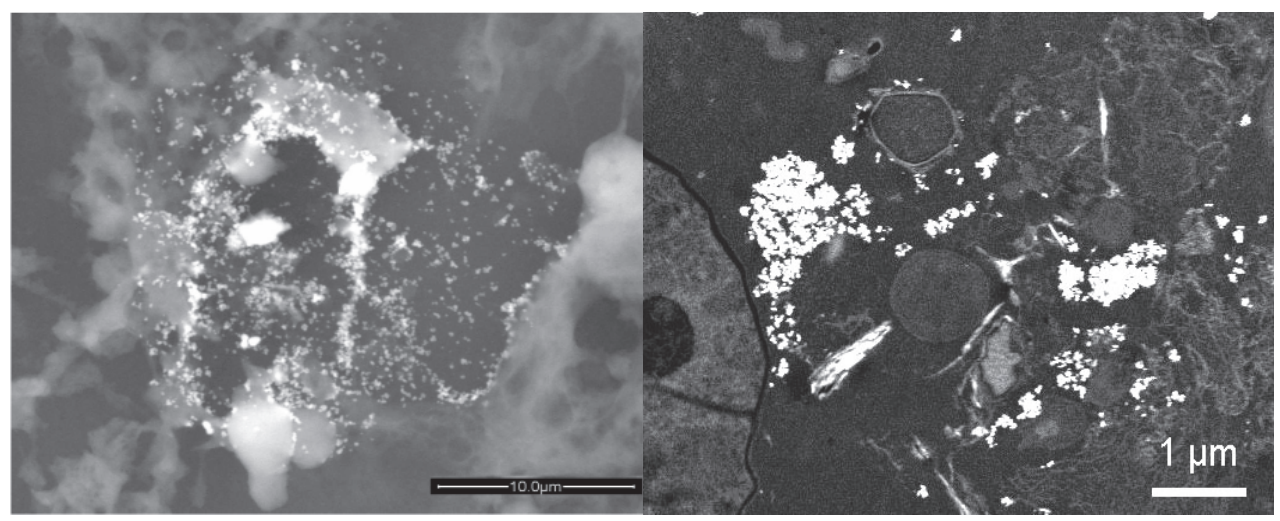

Fig. 3. Nanoparticles of lead compound located in lung where patient was affected by multiorgan granulomatosis (left), and scanning transmission electrograph of ceria nanoparticles exposed to clearing sludge (high-density cerium oxide nanoparticles are bright) (right) [29,45].

One latest study showed that, after 12 weeks of inhalation tests, small $\mathrm{TiO}_{2}$ nanoparticles 20 $\mathrm{nm}$ in size were characterized by a longer retention time in the lungs of rats and increased translocation to interstitial sites than larger $\mathrm{TiO}_{2}$ nanoparticles $250 \mathrm{~nm}$ in size [4,50-52]. Another study in healthy animals also showed that inhalation of metallic nanoparticles (less than $30 \mathrm{~nm}$ ) into the circulatory system was much faster than that of non-metallic nanoparticles (between $4 \mathrm{~nm}$ and $200 \mathrm{~nm}$ ) [53]. Although the mechanism of nanomaterial penetration is not fully understood, it is believed that nanoparticles can be absorbed by lung cells and induce local effects, leading to long-term consequences of airway inflammation, bronchitis, asthma, emphysema, lung cancer, neurodegenerative diseases, and cardiovascular effects [4-6].

Carbon-based nanomaterials (CBNs) in different forms of fullerenes, single- and multiwalled carbon nanotubes (SWCNTs and MWCNTs), and carbon nanoparticles and nanofibers are being used in a number of different applications [1-3]. The shape of CBNs is an important factor in determining its toxicity [42]. Some CBNs are structurally similar to asbestos, raising concerns that widespread use of carbon nanotubes may lead to mesothelioma, cancer of the lining of the lungs caused by an exposure to asbestos. In particular, the needle-like fiber shapes of CNTs are more toxic than other CBNs are to human skin fibroblasts [46-49]. MWCNTs and SWCNTs have strong chemical stability, and when inhaled, they cannot be easily dissolved in the body, which in turn could damage cells, DNA, and surrounding tissues [42-44]. Generally, SWCNTs are more toxic than MWCNTs because of their size [6]. Recent studies have also shown that sidewallfunctionalized MWCNTs and SWCNTs were less toxic to human cells than those without 
functionalization. Also, it is interesting to note that CNTs synthesized by a catalytic chemical vapor deposition are not toxic to human umbilical vein endothelial cells [4,32-34]. Although nanomaterials have superior properties in various applications, they can be very dangerous if not properly handled. Toxicity of nanomaterials has not been completely identified yet, and most studies have mainly focused on acute and liver toxicity $[4,49]$. Longterm toxicity of nanomaterials and examination of chronic exposure must be studied in detail to understand the mechanisms involved. Even though several factors are involved in nanomaterial toxicity, more efforts and time are needed to conduct research on nanoscale products and lung and other diseases $[6,50]$.

\section{Protection methods}

Hazard reduction of nanomaterials is necessary for students, engineers, and health professionals working on their production, processing, and analysis, as well as workers and consumers in contact with commercial products [5,35,36]. Table 2 provides a hierarchy of the exposure controls of nanomaterials at different categories, such as elimination, substitution, engineering, administration, and personal protective equipment $[9,37]$.

\begin{tabular}{|c|c|}
\hline Control Methods & Process, Equipment, and Tasks \\
\hline Elimination & $\begin{array}{l}\text { Change design to eliminate or minimize hazardous } \\
\text { materials. }\end{array}$ \\
\hline Substitution & $\begin{array}{c}\text { Replace high-hazard material with a low one (e.g., } \\
\text { environmental). }\end{array}$ \\
\hline Engineering & $\begin{array}{l}\text { Use isolation/enclosure, ventilation, filtration, and } \\
\text { collection. }\end{array}$ \\
\hline Administration & $\begin{array}{c}\text { Adhere to procedures, policies, shift design, and new rules } \\
\text { and regulations. }\end{array}$ \\
\hline $\begin{array}{l}\text { Personal Protective } \\
\text { Equipment }\end{array}$ & Use respirators, clothing, gloves, goggles, and ear plugs. \\
\hline
\end{tabular}

Table 2. The hierarchy of exposure controls of nanomaterials and their controls [9,37].

The processing, equipment, and job tasks associated with the control methods are as follows: $i$ ) change the design to eliminate or minimize hazardous materials; $i$ ) replace a high-hazard material with a low one; iii) use isolation, ventilation, filtration, and dust collection; iv) adhere to procedures, policies, shift design, and new rules and regulations; and $v$ ) use respirators, clothing, gloves, goggles, and ear plugs. Figure 4 shows some methods of protection that should be used during the production and use of nanomaterials [5,35], which are outlined as follows [4-6]:

- Students, workers, engineers, doctors, and scientist who are working with nanomaterials and devices are recommended to wear a disposable, typically plastic, body covering over their work clothes during high-exposure activities and to wear long gloves pulled over their sleeves to minimize wrist exposure and other contamination. Other recommendations are antistatic shoes to prevent ignition by static charges, and sticky mats at laboratory entrances to prevent the accidental transfer of nanomaterials in and out of the working area [5]. 
- The hazardous effects of nanomaterials need to be reduced during their production and processing. The waste of nanomaterials should be limited. Outputs are sometimes more hazardous than the products or wastes from such activities [5].

- Workers who inhale nanomaterials are advised to consume milk and unrefined sugar to reduce the toxicity level of nanomaterials [5].

- Nitrile gloves or wrist-length disposable nitrile gloves with extended sleeves must be worn during the handling of nanomaterials (Figure 4). These gloves need to be changed frequently[5].

- For eye protection, safety glasses with side shields must be on the face during the use of nanomaterials in the form of solids, liquids, and aerosols [5].

- Volumes of liquid-based nanomaterials must be limited to the milliliter range $(<200 \mathrm{ml})$ in a sealed container when not in use [5].

- Total particle masses must be limited to the milligram range $(<200 \mathrm{mg})$ and must be manipulated within a high efficient particulate air (HEPA)-filtered laboratory exhaust hood over water-soaked absorbent paper to capture any spilled materials [5].

- Containers of nanomaterials must be labeled with a sign indicating "NANOMATERIALS" [5].

- Nanomaterials are considered to be hazardous materials, so workers should follow all the safety rules necessary in the field and laboratory [5].

- The use of nanomaterials increasing worldwide brings with it several concerns for worker and user safety. Thus, new measurement devices should be developed and used in the specified areas where nanomaterials and devices are produced and utilized.

In addition to the previous information, the National Institute for Occupational Safety and Health (NIOSH) has provided sequential steps for students, workers, engineers, and others who are involved in nanotechnology-related teaching, research, and development $[5,38]$. These steps, shown in Figure 5, will potentially reduce the risk of exposing nanomaterials to personnel and consumers $[5,38]$.
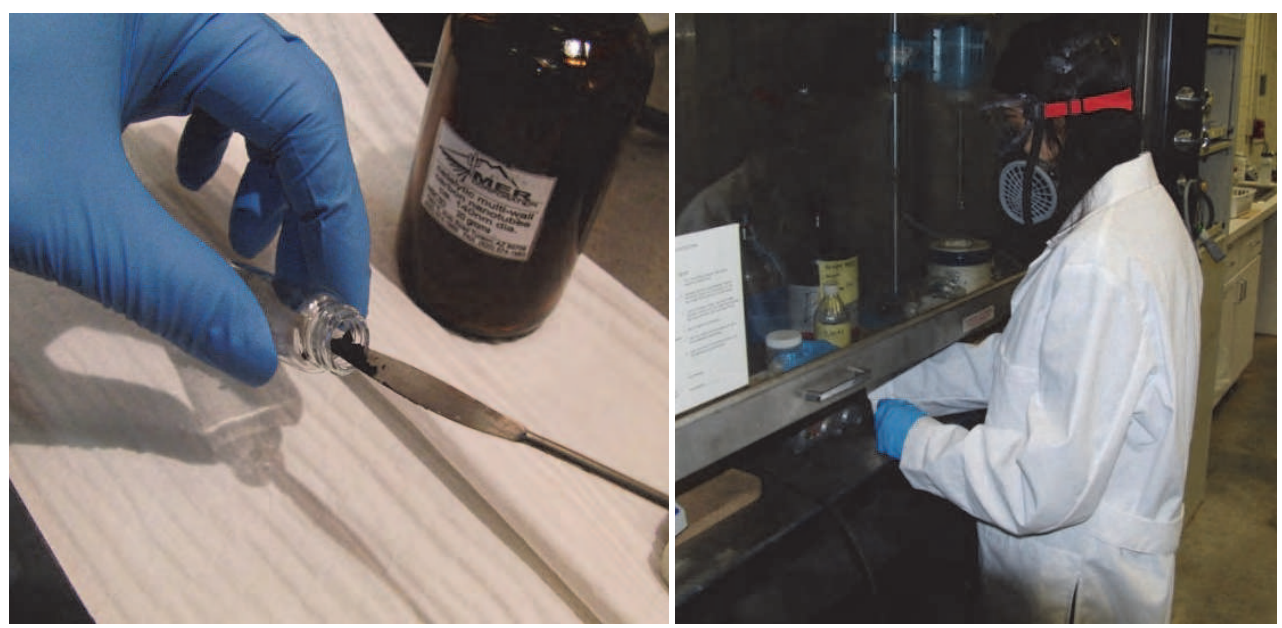

Fig. 4. Simple protection methods for using potentially hazardous engineered nanomaterials in laboratory conditions. 


\section{Steps to Protect Workers Involved with \\ Nanotechnology}

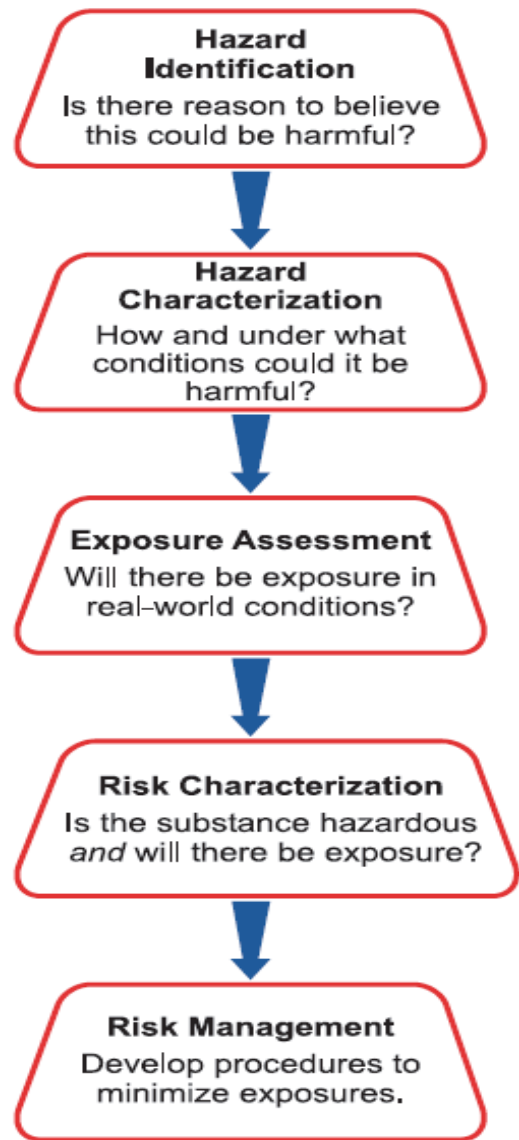

NIOSH Focus

- Toxicologic Research

- Health Effects Assessment

- Safety Research

- Toxicologic Research

- Field Assessment
- Metrology Research
- Field Assessment
- Control Technology Research
- Personal Protective Equipment
(PPE) Research

- Risk Assessment

- Dose Modeling

- Exposure Characterization
- Risk Communication

- Guidance Development for Controls. Exposure Levels, PPE, and Medical Surveillance

- Information Dissemination

Fig. 5. Steps of NIOSH for workers/students involved in nanotechnology processes [5].

\section{Conclusions}

Although nanomaterials have superior properties for various applications, these materials could be more hazardous to human than their microscale equivalent if not properly handled or used. The nanomaterials mainly exposed through inhalation of suspended nanoscale particulates result in the inflammation of airways, bronchitis, asthma, emphysema, lung cancer, neurodegenerative diseases, and cardiovascular effects. Toxicity of nanomaterials has not been completely identified yet, and most studies have focused primarily on acute liver toxicity. The long-term toxicity of nanomaterials and examination of chronic exposure to these materials must be studied in detail to understand their toxicology mechanisms in the lungs and other organs. Even though several factors are involved in the toxicity of nanomaterials, more efforts and time are needed to study nanoproducts, their properties, 
and processing. Thus, students, scientists, engineers, doctors, policymakers, and regulators working in the field should take all the necessary precautions to protect themselves during the production, handling, and consumption of nanomaterials.

\section{Acknowledgment}

The author gratefully acknowledges Wichita State University for the support of this work.

\section{References}

[1] Rogers, B., Pennathur, S., and Adams, J., Nanotechnology Understanding Small Systems, CRC Press, 2008.

[2] Poole, C.P., Introduction to Nanotechnology, Wiley India Pvt. Ltd., 2009.

[3] Gogotsi, Y., Nanomaterials Handbook, CRC Press, 2006.

[4] Kumar, C., Nanomaterials - Toxicity, Health and Environmental Issues, Wiley-VCH, 2006.

[5] "Approaches to Safe Nanotechnology Managing the Health and Safety Concerns Associated with Engineered Nanomaterials," DHHS (NIOSH) Publication 2009125.

[6] Karakoti, A.S., Hench, L.L., and Seal, S., "The Potential Toxicity of Nanomaterials - The Role of Surfaces," JOM Journal of the Minerals, Metals and Materials Society, Vol. 58, 2006, pp. 77-82.

[7] Brayner, R., “The Toxicological Impact of Nanoparticles," Nanotoday, Vol. 3, 2008, pp. 4855.

[8] Asmatulu, R., Asmatulu, E., and Yourdkhani, A., "Toxicity of Nanomaterials and Recent Developments in the Protection Methods," SAMPE Fall Technical Conference, Wichita, KS, October 19-22, 2009, 12 pages.

[9] Asmatulu, R., Asmatulu, E., and Yourdkhani, A., "Importance of Nanosafety in Engineering Education," ASEE Midwest Conference, Lincoln, NB, September, 2009, 8 pages.

[10] Asmatulu, R., Khan, W.S., Asmatulu, E., and Ceylan, M., “Biotechnology and Bioethics in Engineering Education," ASEE Midwest Conference, Lawrence, KS, September 22-24, 2010, 10 pages.

[11] Asmatulu, R., Asmatulu, E., and Zhang, B., "Nanotechnology and Nanoethics in Engineering Education," ASEE Midwest Conference, Lawrence, KS, September 2224, 2010, 11 pages.

[12] Navrotsky, A., "Nanomaterials in the Environment, Agriculture, and Technology (NEAT)," Journal of Nanoparticle Research, Vol. 2, 2000, pp. 321-323.

[13] Marchant, G.E., Sylvester, D.J., and Abbott, K.W., "Risk Management Principles for Nanotechnology," Nanoethics, Vol. 2, 2008, pp. 43-60.

[14] Osman, M.T., “Environmental, Health, and Safety Considerations for Producing Nanomaterials," JOM Journal of the Minerals, Metals and Materials Society, Vol. 60, 2008, pp. 14-17.

[15] O'Brien, N., and Cummins, E., "Development of a Three-Level Risk Assessment Strategy for Nanomaterials," Nanomaterials: Risks and Benefits, 2008, Springer, Netherlands, pp. 161-178. 
[16] Singh, S., and Sing, H. N., "Nanotechnology and Health Safety-Toxicity and Risk Assessments of Nanostructured Materials on Human Health," Journal of Nanoscience and Nanotechnology, Vol.7, 2007, pp. 3048-3070.

[17] Oberdörster, G., Oberdörster, E., and Oberdörster, J., "Nanotoxicology: An Emerging Discipline Evolving from Studies of Ultrafine Particles," Environmental Health Perspectives, Vol. 113, 2005, No. 7, pp. 823-839.

[18] Maynard, A.D., "Safe Handling of Nanotechnology," Nature, Vol. 444, 2006, pp. 267269.

[19] Casals, E., Vázquez-Campos, S., Bastús, N.G., and Puntes, V., "Distribution and Potential Toxicity of Engineered Inorganic Nanoparticles and Carbon Nanostructures in Biological Systems," TrAC Trends in Analytical Chemistry, Vol. 27, 2008, pp. 672-683.

[20] Morse, J., "Economic Impact of Nanomanufacturing Initiatives," National Nanomanufacturing, Vol. 2, Issue 3, March, 2009, 3 pages.

[21] Pacheco, K., Schwenz, R.W., and Jones, W.E., Nanotechnology in Undergraduate Education, Oxford University Press, Inc., 2010.

[22] Allhoff, F., Lin, P., Moor, J., and Weckert, J., Nanoethics: The Ethical and Social Implications of Nanotechnology, Wiley, 2007.

[23] Asmatulu, R., Khan, W. S., Asmatulu, E., and Ceylan, M., "Biotechnology and Bioethics in Engineering Education," ASEE Midwest Conference, Lawrence, KS, September 22-24, 2010, 10 pages.

[24] Asmatulu, R., Asmatulu, E., and Zhang, B., "Nanotechnology and Nanoethics in Engineering Education," ASEE Midwest Conference, Lawrence, KS, September 2224, 2010, 11 pages.

[25] Colvin, V.L., "The Potential Environmental Impact of Engineered Nanomaterials," Nature Biotechnology, Vol. 21, 2003, pp. 1166-1170.

[26] U.S. Environmental Protection Agency, 2007 (www.epc.gov).

[27] Yavuz, C.T., Mayo, J. T., Yu, W.Y., Prakash, A., Falkner, J.C., Yen, S., Cong, L., Shipley, J.H., Kan, A., Tomson, M., Natelson, D., and Colvin, V.L. ,"Low-Field Magnetic Separation of Monodisperse Fe3O4 Nanocrystals," Science, Vol. 314, 2006, pp. $964-$ 967.

[28] Hussain, S.M., Braydich-Stolle, L., Schrand, A.M., Murdock, R.C., Yu, K.O., Mattie, D.M., Schlager, J.J., and Terrones, M., "Toxicity Evaluation for Safe Use of Nanomaterials: Recent Achievements and Technical Challenges," Advanced Materials, Vol. 21, 2009, pp. 1549-1559.

[29] Gatti, A.M., and Montanari, S., "Nanoparticles and Nanosafety," University of Modena and Reggio Emilia, Laboratory of Biomaterials, European Commission, ICNT 2005, San Francisco.

[30] Gatti, A.M., Montanari, S., Monari, E., Gambarelli, A., Capitani, F., and Parisini, B., "Detection of Micro- and Nano-Sized Biocompatible Particles in the Blood," Journal of Materials Science: Materials in Medicine, Vol. 15, 2004, pp. 469-472.

[31] Gatti, A., Montanari, S., Gambarelli, A., Capitani, F., and Salvatori, R., "In-vivo Shortand Long-Term Evaluation of the Interaction Material-Blood," Journal of Materials Science: Materials in Medicine, Vol. 16, No. 12, 2005, pp. 1213-1219.

[32] Monteiro-Riviere, N.A., and Inman, A.O., "Challenges for Assessing Carbon Nanomaterial Toxicity to the Skin," Carbon, Vol. 44, 2006, pp. 1070-1078. 
[33] Grabinski, C., Hussain, S., Lafdi, K., Braydich-Stolle, L., and Schlager, J., "Effect of Particle Dimension on Biocompatibility of Carbon Nanomaterials," Carbon, Vol. 45, 2007, pp. 2828-2835.

[34] Hurt, R.H., Monthioux, M., and Kane, A., “Toxicology of Carbon Nanomaterials: Status, Trends, and Perspectives on the Special Issue," Carbon, Vol. 44, 2006, pp. 1028-1033.

[35] Borisenko, V.E., and Ossicini, S. What is What in the Nanoworld: A Handbook on Nanoscience and Nanotechnology, Weinheim, Wiley-VCH, 2005.

[36] Buzea, C., Pacheco, I.I., and Robbie, K., "Nanomaterials and Nanoparticles: Sources and Toxicity," Biointerphases, Vol. 2, 2007, 55 pages.

[37] Brayner, R., Ferrari-Iliou, R., Brivois, N., Djediat, S., Benedetti, M.F., and Fiévet, F., "Toxicological Impact Studies Based on Escherichia Coli Bacteria in Ultrafine ZnO Nanoparticles Colloidal Medium," Nano Letters, Vol. 6, 2006, pp. 866-870.

[38] http://www.cdc.gov/niosh/, accessed March 15, 2011.

[39] Ramesh, K.T., Nanomaterials: Mechanics and Mechanisms, New York, Springer, 2009.

[40] Kashiwada, S., "Distribution of Nanoparticles in the See-through Medaka (Oryzias latipes)," Environmental Health Perspectives, Vol. 114, No. 11, 2006, pp. 1697-1702.

[41] Braydich-Stolle, L., Hussain, S., Schlager, J.J., and Hofmann, M.C., "In Vitro Cytotoxicity of Nanoparticles in Mammalian Germline Stem Cells," Toxicological Sciences, Vol. 88, 2005, pp. 412-419.

[42] Jia, G., Wang, H., Yan, L., Wang, X., Pei, R., and Yan, T., "Cytotoxicity of Carbon Nanomaterials: Single-Wall Nanotube, Multi-Wall Nanotube, and Fullerene," Environmental Science and Technology, Vol. 39, 2005, pp. 1378-1383.

[43] Nel, A., Xia, T., Madler, L., and Li, N., "Toxic Potential of Materials at the Nanolevel," Science, Vol. 311, 2006, pp. 622-627.

[44] Service, R.F., "Calls Rise for More Research on Toxicology of Nanomaterials," Science, Vol. 310, 2005, pp. 1609.

[45] Limbach, L.K., Bereiter,R., Müller, R., Krebs, R., Gälli, R., and Stark, W.J., “Removal of Oxide Nano-particles in a Model Waste-water Treatment Plant: Influence of Agglomeration and Surfactants on Clearing Efficiency," Environmental Science and Technology, Vol. 42, No. 15, 2008, pp. 5828-5833.

[46] Wu, M., Gordon, R.E., Herbert, R., Padilla, M., Moline, J., Mendelson, D., Litle, V., Travis, W.D., and Gil, J., "Case Report: Lung Disease in World Trade Center Responders Exposed to Dust and Smoke: Carbon Nanotubes Found in the Lungs of World Trade Center Patients and Dust Samples," Environmental Health Perspectives, Vol. 118, No. 4, 2010, pp. 499-504.

[47] Florito, S., Serafino, A., Andreola, F., Togna, A., and Togna, G., "Toxicity and Biocompatability of Carbon Nanoparticles," Journal of Nanoscience and Nanotechnology, Vol. 6, No. 3, 2006, pp. 591-599.

[48] Lam, C., James, J.T., McKluskey, R., Arepalli, S., and Hunter, R., “A Review of Carbon Toxicity and Assessment of Potential Occupational and Environmental Health Risks," Critical Reviews in Toxicology, Vol. 36, No. 3, 2006, pp. 189-217.

[49] Lam, C.W., James, J.T., McCluskey, R., and Hunter, R.L., "Pulmonary Toxicity of Singlewall Carbon Nanotubes in Mice 7 and 90 Days after Intratracheal Instillation," Toxicological Sciences, Vol. 77, 2004, pp. 126-134. 
[50] Keenan, C.R., Goth-Goldstein, R., Lucas, D., and Sedlak, D.L., “Oxidative Stress Induced by Zero-Valent Iron Nanoparticles and Fe(II) in Human Bronchial Epithelial Cells," Environmental Science and Technology, Vol. 43, No. 12, 2009, pp. 4555-4560.

[51] Wang, B., Feng, W., Zhao, Y., Xing, G., Chai, Z., Wang, H., and Jia, G., "Status of Study on Biological and Toxicological Effects of Nanoscale Materials," Science in China Series B: Chemistry, Vol. 48, 2005, pp. 385-394.

[52] Hosokawa, M., Nogi, K., Naito, M., and Yokoyama, T., Nanoparticles Technology Handbook, Elsevier, 2007.

[53] Seaton, A., Tran, L., Aitken, R., and Donaldson, K., "Nanoparticles, Human Health Hazard and Regulation," Journal of the Royal Society Interface, Vol. 7, 2010, pp. S119S129. 


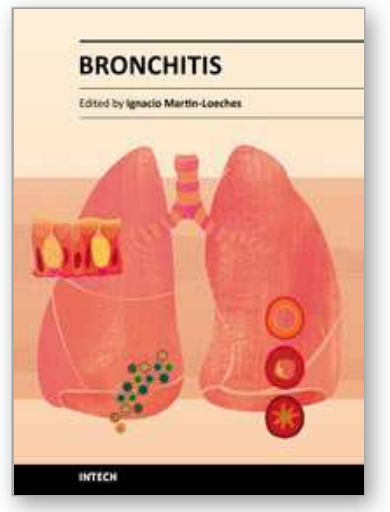

\author{
Bronchitis \\ Edited by Dr. Ignacio MartÃn-Loeches
}

ISBN 978-953-307-889-2

Hard cover, 190 pages

Publisher InTech

Published online 23, August, 2011

Published in print edition August, 2011

Lung parenchyma has been extensively investigated. Nevertheless, the study of bronchial small airways is much less common. In addition, bronchitis represents, in some occasions, an intermediate process that easily explains the damage in the lung parenchyma. The main target of this book is to provide a bronchial small airways original research from different experts in the field.

\title{
How to reference
}

In order to correctly reference this scholarly work, feel free to copy and paste the following:

R. Asmatulu (2011). Toxicity of Nanomaterials and Recent Developments in Lung Disease, Bronchitis, Dr. Ignacio MartÃn-Loeches (Ed.), ISBN: 978-953-307-889-2, InTech, Available from:

http://www.intechopen.com/books/bronchitis/toxicity-of-nanomaterials-and-recent-developments-in-lungdisease

\section{INTECH}

open science | open minds

\section{InTech Europe}

University Campus STeP Ri

Slavka Krautzeka 83/A

51000 Rijeka, Croatia

Phone: +385 (51) 770447

Fax: +385 (51) 686166

www.intechopen.com

\section{InTech China}

Unit 405, Office Block, Hotel Equatorial Shanghai

No.65, Yan An Road (West), Shanghai, 200040, China

中国上海市延安西路65号上海国际贵都大饭店办公楼 405 单元

Phone: +86-21-62489820

Fax: +86-21-62489821 
(C) 2011 The Author(s). Licensee IntechOpen. This chapter is distributed under the terms of the Creative Commons Attribution-NonCommercialShareAlike-3.0 License, which permits use, distribution and reproduction for non-commercial purposes, provided the original is properly cited and derivative works building on this content are distributed under the same license. 